\title{
PENGUJIAN EMPIRIS BAGAIMANA KUALITAS SISTEM INFORMASI AKUNTANSI YANG DIPENGARUHI OLEH ETIKA ORGANISASI BERIMPLIKASI TERHADAP KUALITAS INFORMASI AKUNTANSI
} (SurveyPada Badan Usaha Milik Negara (BUMN) di Sumatera Selatan Indonesia)

\author{
${ }^{1,2}$ Lesi Hertati, ${ }^{3}$ Azhar Susanto ${ }^{4}$ Wahyudin Zarkasyi, ${ }^{5}$ Harry Suharman, ${ }^{6}$ Haryono Umar \\ ${ }^{1}$ Lecturer, Department of Accounting, STIE Rahmaniyah - Indonesia \\ ${ }^{6}$ Lecturer, Department of Accounting, Perbanas Institute, Indonesia \\ ${ }^{2}$ Doctoral Students of Science Accountancy Department, Faculty of Economics and \\ Business,Padjadjaran University, Dipati Ukur Steet, Bandung, Indonesia and \\ ${ }^{2.3 .4}$ Lecturer at the Faculty of Economics and Business, Padjadjaran University, \\ Dipati Ukur Steet, P.O box 40132, Bandung, Indonesia \\ hertatilesi@yahoo.co.id,
}

\begin{abstract}
ABSTRACK
Accounting Information System is one of the most important parts in an organization. Function Organizational ethics is very influential on accounting information systems will produce accounting information needed by managers and non-managers of an organization as a basis for the decision making process in carrying out its functions or duties. The functions and tasks of managers or non-managers of related units within an organization vary greatly depending on the type of organization, the sections and levels that exist within the organization. The functions and tasks of managers or non-managers differ because the different levels and sections that cause the information needs of managers and nonmanagers are to support different functions and tasks. The difference in information requirements will lead to different data that must be entered and the accounting information system format used. Reality states that many accounting information systems in various state-owned enterprises have a variety of problems including problems of integration, ease of use, ease of access, ease of adaptation to changing conditions and the ability to produce accounting information as needed. The purpose of this study was to determine how much influence the organization's ethics has on the quality of accounting information systems and their implications for the quality of management accounting information. This method is descriptive and verification method, and the analysis tool is SEM Lisrel modeling. The results showed that user ethics significantly influence the quality of accounting information systems and their implications for the quality of accounting information.
\end{abstract}

Keywords :Etika Organisasi, Sistem Informasi Akuntansi, Informasi Akuntansi

\section{PENDAHULUAN}

Peran akuntansi dalam menghadapi masa disrupsi teknologi yang berkembang sangat pesat, sehingga detik demi detik menggantikan peran manusia. Jika sumberdaya manusia tidak bisa beradaptasi dengan teknologi secara 
Hertanti, Susanto, Zarkasyi, Suharman \& Umar flexible maka profesi akuntansi akan dikalahkan oleh mesin atau program Komputer, dimana akuntansi harus mengikuti trend teknologi informasi yang begitu cepat. Kemudian Hertati (2019) menyatakan akuntansi bagian dari sistem informasi yang memberi informasi secara online atau daring dengan sistem manajemen yang baik akan dapat memantau kemajuan teknologi cepat guna menuju industry 4.0. Selanjutnya teknologi informasi industri 4.0 adalah trend didunia industri yang menggabungkan teknologi otomatisasi dengan teknologi cyber (Hertati 2016).Lebih jauh Hertati (2016) menyatakan bahwa industri 4.0, merupakan teknologi manufaktur yang masuk dalam trend otomatisasi guna pertukaran data.

Revolusi industry 4.0 memiliki prinsip yang memungkinkan setiap perusahaan untuk mengidentifikasi teknologi informasi yangmengimplementasikan berbagai skenario industri 4.0, diantaranya adalah interoperabilitas (kesesuaian); kemampuan mesin, perangkat, sensor, dan manusia untuk terhubung dan saling berkomunikasi satu sama lain melalui media internet secara terintegrasidengan akuratdalam internet untuk khalayak.Keputusan mandiri seperti kemampuan sistem siber-fisik untuk membuat keputusan dan melakukan tugas semandiri mungkin (Hertati (2019: Susanto (2018).

Susanto (2018) menyatakan bahwa Globalisasi dan perubahan ekonomi dari ekonomi berbasis industri ke ekonomi berbasis informasi menuntut manajemen bisnis untuk dapat beroperasi lebih efektif, efisien dan terkendali dengan mempromosikan keunggulan kompetitif baik secara lokal maupun global dengan meningkatkan kualitas sumber daya manusia, barang dan jasa yang dihasilkan dan penggunaan teknologi informasi melalui sistem informasi (Susanto, 2013: 1). Penerapan sistem informasi akuntansi digunakan untuk membantu manajer perusahaan dan profesional dalam menyelesaikan berbagai masalah ketika melakukan bisnis dengan memberikan informasi akuntansi yang berkualitas sehingga kinerja manajer lebih baik (O'Brien \& Maracas, 2014: 18; Susanto, 2015: 326).

Sistem informasi akuntansi merupakan integrasi dari berbagai sistem pemrosesan transaksi (Susanto, 2013: 216). Bodnar \& Hapwood (2014; 1), menyatakan bahwa sistem informasi akuntansi adalah kumpulan seperangkat 
Hertanti, Susanto, Zarkasyi, Suharman \& Umar sumber daya seperti manusia dan peralatan yang didukung yang dirancang untuk mengubah data akuntansi menjadi informasi akuntansi yang dibutuhkan oleh manajer dan manajer non-pengguna dalam proses pengambilan keputusan. Dalam suatu organisasi, Sistem Informasi Akuntansi adalah salah satu sistem informasi yang paling penting (Wilkinson et.al, 2000: 18), didukung oleh pernyataan Bockholdt $(1999,1)$ yang menyatakan bahwa sistem informasi akuntansi ada di seluruh organisasi, segala bentuk organisasi. Di dalam organisasi perusahaan, sistem informasi akuntansi digunakan oleh perusahaan untuk mendukung berbagai kegiatan yang berkaitan dengan transaksi keuangan, baik transaksi itu terjadi di dalam atau di luar perusahaan (Susanto, 2013: 95).

Dukungan yang diberikan oleh sistem informasi akuntansi adalah untuk memproses setiap data keuangan atau akuntansi yang bersumber dari berbagai peristiwa untuk menghasilkan informasi akuntansi pada suatu sistem informasi dikatakan berkualitas jika secara umum ia memiliki fitur karakteristik: fleksibel, efisien, dapat diakses, dan tepat waktu dalam memberikan informasi(Bockholdt, 1999: 31: Gelinas dan Dull, 2008: 21: Post \& Anderson (2003: 5: Stair \& Reynolds (2012: 32). Sistem informasi dan etika saling mempengaruhi, perusahaan tidak akan berhasil merancang sistem informasi baru atau memahami sistem yang ada tanpa memahami kegiatan bisnis organisasi yang sedang berlangsung (Laudon dan Laudon, 2014: 111). Pemahaman tentang aliran proses, tanggung jawab, wewenang dan akuntabilitas penting dalam menilai informasi apa yang dibutuhkan oleh pengguna (Hall, 2011: 15: Susanto, 2018).

Setiap manajer di berbagai tingkatan dan bagian dari suatu organisasi memiliki peran yang berbeda satu sama lain, karena itu pengelolaan organisasi di berbagai tingkatan dan bagian akan memerlukan informasi yang berbeda. Sistem informasi akuntansi dibangun untuk mengalirkan informasi berdasarkan informasi yang dibutuhkan oleh pengguna di setiap level hierarki dalam struktur organisasi perusahaan untuk membantu mereka dalam mengambil keputusan saat melakukan tugasnya (Susanto, 2015: 332). Semakin besar tingkat hierarki dalam etika organisasi perusahaan, semakin luas dan kompleks kegiatan perusahaan, maka sistem informasi akuntansi yang dibangun akan semakin kompleks (Scott, 2001:8) 
Hertanti, Susanto, Zarkasyi, Suharman \& Umar

Etika organisasi berkontribusi pada implementasi sistem informasi akuntansi untuk memperluas distribusi informasi ke level terendah organisasi dengan tujuan untuk digunakan oleh karyawan pada level yang lebih rendah dalam proses pengambilan keputusan (Laudon dan Laudon, 2014: 91). Etika organisasi menentukan jumlah aliran informasi akuntansi yang dihasilkan dari sistem informasi akuntansi dalam suatu organisasi (Wilkinson.et.al, 2000: 39).

Etika organisasidalam menjalankan tugasnya guna pengembangan sistem, memastikan bahwa konsep etikanya menyebar di seluruh organisasi, melalui semua tingkatan dan menyentuh semua karyawan (McLeod \& Schell, 2007:234). Oleh karena itu, peningkatan perilaku etis harus dimulai dari manajemen (Griffin, 2011:108). Etika merupakan satu set kepercayaan, standar atau pemikiran yang mengisi suatu individu, kelompok atau masyarakat (McLeod \& Schell, 2007:232). Etika menurut Laudon \& Laudon (2014:155) merupakan prinsip-prinsip mengenai kebenaran dan kekeliruan yang dapat digunakan individu, bertindak sebagai agenagen moral bebas, dalam membuat pilihan-pilihan untuk menuntun perilakunya.

Sehingga dapat dikatakan sistem informasi diimplementasikan, etika organisasi yang sangat penting sebagai pedoman bagi pihak manajemen dalam rangka pengembangan teknologi yang sedang diterapkan (Piccoli, 2008:450), senada dengan Rogerson et al. (2000) yang menyatakan bahwa etika berkaitan dengan pengembangan sistem informasi. Laudon \& Laudon (2014:155) mengungkapkan bahwa konsep dasar etika dalam penggunaan sistem informasi terdiri dari tanggung jawab (responsibility), akuntabilitas (accountability) dan liabilitas (liability).Selanjutnya Bagranoff et al. (2010:334) menyatakan etika dalam penggunaan komputer adalah honesty, protecting computer systems, protecting confidential information, social responsibility, acceptable use dan rights of privacy.Senada dengan Hansen \& Mowen (2007:17) bahwa yang menjadi prinsip etika adalah honesty, integrity, promise keeping, fidelity, fairness, caring for others, respect for others, responsible citizenship, pursuit of excellence dan accountability.

Kondisi etika yang menyimpang yang terjadi di BUMN disampaikan oleh Hasan Basri (2013) bahwa BPK menemukan banyak kasus BUMN yang merekayasa pembukuan supaya keuntungannya besar, sehingga bonusnya jadi 
Hertanti, Susanto, Zarkasyi, Suharman \& Umar besar.Selanjutnya Azhar Aziz (2014) menyatakan bahwa nilai penyimpangan anggaran yang dilakukan badan usaha milik negara cenderung naik.Modus yang menyebabkan kerugian Negara tahun 2014 mencapai Rp. 527 miliar.Modus ini umumnya dipakai dalam proyek pembangunan gedung dan pemeliharaan infrastruktur. Fenomena lainnya berupa terjadi kasus dugaan korupsi penjualan tanah milik PT Barata Indonesia dengan modus penjualan tanah milik PT Barata dengan cara diturunkan harganya dari harga NJOP yang berlaku tahun 2004 (Johan Budi, 2011). Potensi pelanggaran etika memungkinkan munculnya eksposur bagi organisasi (Bodnar \& Hopwood, 2014:115).

Dapat dikatakan bahwa etika organisasi sangat diperlukan dalam menjalankan aktivitas organisasi untuk mencapai hasil berupa kinerja yang profesional yang merupakan faktor yang berdampak pada keberlangsungan sistem informasi (Ballantine et al., 2000).Keberlangsungan sistem informasi tidak terlepas dari etika organisasi yang menjalankan fungsi organisasi dalam hal ini sistem informasi (Bodnar \& Hopwood, 2014:17).

Fenomena informasi akuntansi di Indonesia belum memenuhi karakteristik informasi akuntansi yang berkualitas, sebagaimana dikemukakan oleh terjadi di BUMN, terdapat 510 kasus penyimpangan keuangan negara yang menuntut atas transparansi informasi akuntansi yang lebih akurat dan mendalam (Sumarjati Arjoso, 2013), catatan keuangan yang tidak akurat (Uchok Sky Khadafi, 2012) dan sejumlah dokumen bermasalah, setidaknya terdapat 30 BUMN memiliki kinerja keuangan yang buruk serta terindikasi bermasalah dalam kinerja dan keuangan dimana ikhtisar laporan keuangan perusahaan negara kurang efektif dan kurang akuntabel.

Informasi yang berkualitas diproses melalui sistem informasi (Bodnar \& Hopwood, 2014:6: Gelinas et al., 2012:18) .Sistem informasi akuntansi merupakan alat yang memberikan informasi akuntansi yang diperlukan kepada semua pihak yang berkepentingan (Susanto, 2013:58).Dapat dikatakan bahwa peran mendasar sistem informasi akuntansi dalam organisasi adalah menghasilkan informasi akuntansi yang berkualitas (Susanto, 2013:374).Oleh karena itu, sistem informasi akuntansi harus dapat diterima dan digunakan oleh seluruh karyawan dalam organisasi (Laudon \& Laudon, 2014:45). 
Hertanti, Susanto, Zarkasyi, Suharman \& Umar

\section{LANDASAN TEORI}

\subsection{Etika Organisasi}

Dessler (2013:461) menyatakan etika mengacu pada prinsip-prinsip perilaku yang mengatur individu atau kelompok yang menggunakan standar perilaku yang harus dilakukan.Penerapan etika sangat penting bagi seluruh profesi (Schwalbe, 2006:30).Sependapat dengan Piccoli (2008:447) dapat diartikan bahwa etika merupakan disiplin yang berurusan dengan perilaku yang baik dan buruk dan dengan kewajiban moral dan kewajiban. Etika adalah cabang filsafat yang menilai dirinya dengan moralitas dengan mempelajari benar dan salah dan mencoba untuk menarik perbedaan antara yang baik dan yang buruk.

Pendapat tersebut senada dengan Bagranoff et al. (2010:333) bahwa etika adalah seperangkat prinsip moral atau nilai-nilai.Oleh karena itu, perilaku etis melibatkan membuat pilihan dan penilaian yang diterima secara moral dan melakukan tindakan yang sesuai.Senada dengan Bagranoff et al. (2010:333), Hall (2011:112) mengungkapkan bahwa etika berkaitan dengan prinsip-prinsip perilaku individu yang digunakan dalam membuat pilihan dan membimbing perilaku mereka dalam situasi yang melibatkan konsep benar dan salah.Menurut Simkin et al. (2012:361) etika adalah seperangkat prinsip moral atau nilai.Selanjutnya McLeod \& Schell (2007:262) menyatakan bahwa etika adalah satu set kepercayaan, standar atau pemikiran yang mengisi suatu individu,kelompok atau masyarakat. Semua individu bertanggung jawab kepada masyarakat atas perilaku mereka.

Etika pengguna merupakan prinsip moral bagi seseorang yang berkaitan dengan perilaku baik dan buruk dalam menjalankan aktivitas sistem informasi akuntansi.Selanjutnya Robbins \& Judge (2014:92) menyatakan terdapat 3 (tiga) kriteria etika antara lainutilitarianism, whistle-blowers dan creativity. Laudon \& Laudon (2014:159-160) mengungkapkan konsep dasar dari etika pengguna dalam penerapan sistem informasi antara lain :

1) Tanggung jawab (responsibility)

Tanggung jawab adalah unsur kunci dari tindakan etis yang berarti menerima dari segala bentuk biaya, tugas dan keharusan dari keputusan yang dibuat. 
Hertanti, Susanto, Zarkasyi, Suharman \& Umar

2) Akuntabilitas (accountability)

Akuntabilitas dari sistem dan institusi sosial, artinya mekanisme ada pada tempatnya dalam menentukan siapa yang bertanggung jawab, siapa yang bertindak.

3) Kewajiban (liability).

Sesuatu tindakan yang harus dilakukan seseorang sebagai bentuk tanggung jawab atas permasalahan tertentu, baik secara moral.

\subsection{Sistem Informasi Akuntansi}

Gelinas et al. (2012:15) mengemukakan bahwa sistem informasi akuntansi (SIA) merupakan sub sistem khusus dari sistem informasi. Tujuan dari SIA adalah untuk mengumpulkan, memproses, dan melaporkan informasi yang berkaitan dengan aspek keuangan atas peristiwa bisnis.Kemudian Hall (2011:7) memasukkan istilah transaksi keuangan dan non keuangan ke dalam pengertian sistem informasi akuntansi.Bodnar \& Hopwood (2014:1) menyatakan pula bahwa sistem informasi akuntansi (SIA) adalah kumpulan sumber daya, seperti orang dan peralatan, yang dirancang untuk mengubah data keuangan dan lainnya menjadi informasi.Informasi ini dikomunikasikan kepada berbagai pengambil keputusan(Hall 2011:7. Berdasarkan beberapa penjelasan di atas, dapat dikatakan bahwa sistem informasi akuntansi merupakan kumpulan dari komponenkomponen yang saling berkaitan satu sama lainnya yang secara bersama-sama menjalankan fungsi untuk mengolah data transaksi berkaitan dengan keuangan menjadi informasi keuangan.

Susanto (2016) mengukur keberhasilan sistem informasi tidak seharusnya diukur hanya melalui efisiensi dalam hal meminimalkan biaya, waktu dan penggunaan sumber daya informasi. Keberhasilan juga diukur dari efektivitas teknologi informasi dalam mendukung strategi bisnis, memungkinkan proses bisnisnya, meningkatkan struktur organisasi dan budaya, serta meningkatkan nilai pelanggan dan bisnis perusahaan.Susanto, (2016), menyatakan bahwa kualitas sistem informasi akuntansi merupakan kemampuan sistem informasi dalam menyediakan informasi akuntansi yang berkualitas yaitu sesuai dengan kebutuhan 
Jurnal Ilmiah Akuntansi Rahmaniyah (JIAR)

Vol. 3 No.1, Desember 2019, $88-107$

Hertanti, Susanto, Zarkasyi, Suharman \& Umar

user dan berguna dalam pengambilan keputusan, dengan menggunakan karakteristik:

1. Integration

Sistem infomasisubsekumpulan sistem/komponen baik fisik maupun non fisik yang saling berhubungan dan bekerja sama satu sama lain secara harmonis untuk mengolah data transaksi yang berkaitan dengan masalah keuangan menjadi informasi keuangan disebut dengan sistem informasi akuntansi

2. Flexibility

Sistem infomasikemampuan dari sebuah sistem informasi dalam menyikapi atau merespon kebutuhan pengguna akan requirement yang baru, berbeda, atau berubah.

3. Reliability

Sistem infomasi handal artinya dapat dipercaya bebas dari kesalahan.

\subsection{Informasi Akuntansi}

Kualitas informasi akuntansi yaitu produk informasi yang memiliki karakteristik, atribut atau kualitas yang membuat informasi lebih bernilai.Informasi memiliki tiga dimensi yaitu waktu, konten dan bentuk. Pernyataan O'Brien \& Marakas (2011:390), sependapat dengan Bocij et al. (2015:11) bahwa atribut kualitas informasi adalah sekelompok karakteristik dimana kualitas informasi dapat dinilai, biasanya dikelompokkan ke dalam kategori waktu, isi dan bentuk. Senada dengan yang disampaikan Susanto (2013:38) menyatakan informasi yang berkualitas merupakan informasi yang mempunyai keakurasian, kecepatan dan kesesuaian dengan kebutuhan manajemen dan kelengkapan dari informasi yang dihasilkan.Informasi yang berkualitas merupakan kunci keberlangsungan suatu organisasi dan dalam pengambilan keputusan yang efektif (Koskosas et al., 2011). Hall (2011:13). Kualitas informasi akuntansi merupakan informasi keuangan seperti neraca, laba rugi, perubahan posisi keuangan, arus kas dan sebagainya yang berguna bagi para pengambil keputusan yang memiliki kriteria accuracy, relevancy, timeliness dan completeness. Informasi yang berkualitas sangat bermanfaat dalam memperbaiki 
Hertanti, Susanto, Zarkasyi, Suharman \& Umar

keputusan yang akan diambil dan secara langsung dapat meningkatkan kondisi organisasi (Baltzan, 2014:219).

Kemudian menurut McLeod \& Schell (2007:65) mengatakan bahwa suatu informasi yang berkualitas harus memiliki ciri-ciri sebagai berikut:

\section{1) Accuracy}

Idealnya, semua informasi harus akurat tetapi peningkatan ketelitian sistem menambah biaya.Karena alasan tersebut, manajer terpaksa menerima ketelitian yang kurang dari sempurna.Berbagai aplikasi yang melibatkan uang, seperti pembayaran gaji, penagihan, dan piutang, menuntut ketelitian 100\%. Beberapa aplikasi lain, seperti ramalan ekonomi jangka panjang dan laporan statistik, sering dapat tetap berguna jika datanya mengandung sedikit kesalahan.

2) Relevancy

Informasi memiliki relevansi jika berkaitan langsung dengan masalah yang ada. Manajer harus mampu memilih informasi yang diperlukan tanpa membaca seluruh informasi mengenai subyek lain.

\section{3) Timeliness}

Informasi harus tersedia untuk memecahkan masalah sebelum situasi krisis menjadi tidak terkendali atau kesempatan menghilang. Manajer harus mampu memperoleh informasi yang menggambarkan apa yang sedang terjadi sekarang, selain apa yang telah terjadi di masa lampau.

\section{4) Completeness}

Manajer harus mampu memperoleh informasi yang menyajikan gambaran lengkap dari suatu permasalahan atau penyelesaian adanya bahaya dari informasi yang terlalu banyak.Manajer harus mampu menentukan jumlah rincian yang diperlukan.

\subsection{Pengaruh Etika Organisasi Terhadap Kualitas Sistem Informasi Akuntansi}

Piccoli (2008:450) menyatakan etika terkait dengan sistem informasi, artinya ketika sistem informasi diterapkan, etika menjadi penuntun bagi perilaku pengguna sesuai dengan aturan yang diterapkan. Laudon \& Laudon (2014:152). mengemukakan bahwa seseorang harus memahami bagaimana beretika yang 
Hertanti, Susanto, Zarkasyi, Suharman \& Umar benar yang diperlukan dalam penggunaan sistem informasi. Hal tersebut didukung oleh pernyataan menurut Rocheleau (2006:264) yang mengungkapkan bahwa etika berkaitan dengan sistem informasi.Lebih lanjut O'Brien \& Marakas (2011:20) menegaskan bahwa sebagai manajer, pengusaha profesional dan karyawan harus memiliki tanggung jawab etis dalam penggunaan sistem informasi. Pendapat lain mengenai keterkaitan etika dengan sistem informasi disampaikan oleh Hall (2011:112) bahwa etika sangat terkait dengan bisnis, sistem informasi dan teknologi komputer.

Hal tersebut dipertegas oleh Simkin et al. (2012:314) bahwa dalam penerapan sistem informasi akuntansi tidak terlepas dari etika pengguna seperti dalam kondisi menyalin informasi secara tidak sah, penyalahgunaan informasi, kejahatan komputer, penipuan informasi.Hasil studi Olumoye (2013) dalam penelitiannya mengungkapkan bahwa etika dalam hal ini tanggung jawab dan akuntabilitas seseorang sangat diperlukan dalam menjalankan aktivitasnya dalam rangka pengembangan sistem informasi.Hal tersebut sependapat dengan Chen et al. (2011) dalam penelitiannya bahwa tanggung jawab pengguna memiliki peran penting dalam meningkatkan kinerja sistem informasi.Guragai et al. (2014) dalam penelitiannya mengungkapkan keterkaitan antara sistem informasi akuntansi dan etika yang perlu diperhatikan jika terjadi kesenjangan untuk memberikan masukan bagi penelitian selanjutnya.

Selanjutnya Rogerson et al. (2000) dalam penelitiannya menyatakan bahwa masalah etika berkaitan dengan implementasi sistem informasi, dapat diartikan apabila perilaku etis diterapkan secara hati-hati dan divalidasi dengan hasil pekerjaan maka diperlukan peningkatan etika yang baik dalam penggunaan sistem informasi.Hasil studi Ballantine et al. (2000) mengungkapkan isu-isu etis adalah unsur penting dan tidak dapat dihindari dari sistem informasi.Sebuah kerangka dikembangkan yang menunjukkan bahwa pertimbangan etika yang tersirat dalam konsep penggunaan sistem informasi dalam hal keterlibatan orang dalam berperilaku.Berdasarkan uraian diatas bahwa kualitas sistem informasi akuntansi ditunjukkan dengan penggunaan sistem informasi akuntansi dan implementasi sistem informasi dalam sebuah organisasi memperhatikan etika dari para 
Hertanti, Susanto, Zarkasyi, Suharman \& Umar pengguna, sehingga dapat dikatakan bahwa etika pengguna berpengaruh terhadap kualitas sistem informasi akuntansi.

\subsection{Pengaruh Kualitas Sistem Informasi Akuntansi Terhadap Kualitas Informasi Akuntansi}

Sistem informasi akuntansi menghasilkan informasi akuntansi (Laudon \& Laudon, 2014:46).Sependapat dengan Mulyani (2014:18) bahwa tujuan sistem informasi akuntansi adalah menyediakan informasi akuntansi yang sesuai dengan kebutuhan organisasi.Susanto (2013:58) menyatakan bagi suatu perusahaan, sistem informasi akuntansi merupakan suatu alat yang dapat memberikan informasi yang diperlukan kepada semua pihak yang berkepentingan.

Gelinas et al. (2012:17) mengemukakan bahwa untuk menghasilkan informasi yang berguna bagi manajemen organisasi, perlu adanya sistem informasi akuntansi yang merupakan hal penting untuk keberhasilan suatu organisasi.Selanjutnya McLeod \& Schell (2007:47) bahwa sistem informasi dikembangkan oleh pengguna atau spesialis informasi untuk menyediakan informasi.Kemudian Bodnar \& Hopwood (2014:15) menyatakan sistem informasi akuntansi yang didalamnya termasuk penggunaan teknologi informasi menghasilkan informasi bagi pengguna.Sependapat dengan Weber (1999:897) bahwa kualitas informasi yang dihasilkan sebuah sistem informasi dipengaruhi oleh kualitas dari sistem informasi tersebut. Alzoubi (2011) dalam penelitiannya menghasilkan kesimpulan bahwa integrasi sistem informasi akuntansi yang di dalamnya sistem ERP dapat menghasilkan output berupa kualitas informasi. Hal tersebut didukung oleh $\mathrm{Xu}$, Hongjiang (2009) bahwa kualitas informasi merupakan salah satu keunggulan kompetitif bagi suatu organisasi dan dihasilkan oleh keberhasilan sistem informasi akuntansi.

Penelitian yang dilakukan oleh Masclet \& Goujon (2012) bahwa sistem informasi dapat diterapkan dengan baik di lingkungan masyarakat, berfungsi menghasilkan informasi.Wongsim \& Jing Gao (2011) menyatakan bahwa sistem informasi akuntansi berpengaruh terhadap kualitas informasi yang selanjutnya digunakan dalam pengambilan suatu keputusan dengan proses adopsi sistem informasi akuntansi. Dimensi kualitas informasi dalam penelitian ini adalah relevance, reliability, comparability, understandability, availability, effectiveness, 
Hertanti, Susanto, Zarkasyi, Suharman \& Umar

efficiency, confidentiality, accessibility, integrity, compliance, accuracy, objectivity, security, completeness dan timeliness.

Hertati(2015) dalam penelitiannya menyimpulkan bahwa kesuksesan sistem informasi akuntansi berdampak terhadap kualitas informasi akuntansi. Selanjutnya penelitian Susanto (2016) menyatakan bahwa kualitas informasi akuntansi dipengaruhi oleh kualitas sistem informasi akuntansi (Munteanu et al. 2007). Selanjutnya Onaolapo \& Odetayo (2012) dan Sajady, et al. (2008) menyatakan manfaat dari sistem informasi akuntansi dapat dievaluasi serta dampaknya terhadap peningkatan proses pengambilan keputusan, kualitas informasi akuntansi, kinerja, pengawasan internal dan memfasilitasi atau memudahkan transaksi perusahaan.

Horan \& Abhichandani (2006) dalam penelitiannya mengungkapkan bahwa karakteristik kualitas sistem informasi terdiri dari utility, reliability, efficiency, customization dan flexibility dan berdampak pada kualitas informasi yang dihasilkannya. Sependapat dengan Gorla et al. (2010) mengukur kualitas sistem dilihat dari bebas dari kesalahan, mudah dipelajari, mudah digunakan, dokumentasi yang baik dan fleksibel yang mempengaruhi informasi yang dihasilkannya. Penelitian Hertati (2015) menyatakan baha informasi akuntansi merupakan konsep yang berhubungan dengan output kualitas sistem informasi yang selanjutnya dapat digunakan dalam pengambilan keputusan. Berdasarkan uraian kerangka pemikiran di atas, maka dapat digambarkan bagan kerangka pemikiran sebagai berikut ;

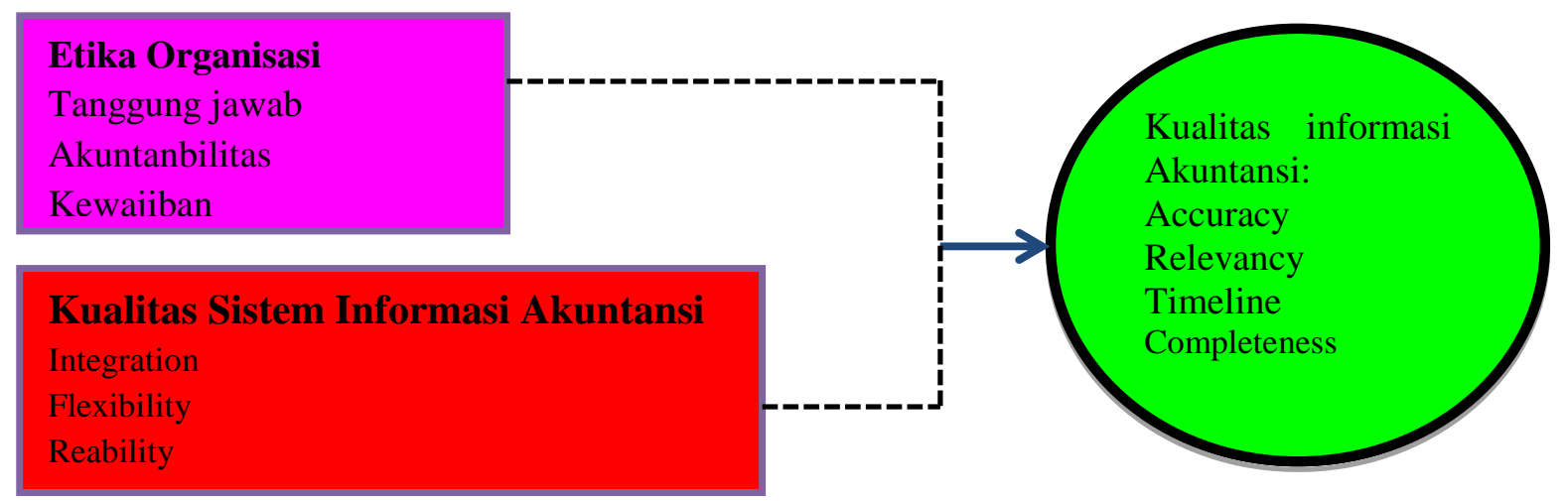

Gambar kerangka pikir Penelitian 
Hertanti, Susanto, Zarkasyi, Suharman \& Umar

Hipotesis:

- Pengaruh Etika Organisasi Terhadap Kualitas Sistem Informasi Akuntansi

- Pengaruh Kualitas Sistem Informasi Akuntansi Terhadap Kualitas Informasi Akuntansi

\section{Metodelogi Penelitian}

Metode yang digunakan dalam penelitian ini adalah penelitian deskriptif dan perifikatif. Populasi dalam penelitian ini adalah badan usaha milik Negara di Suatera Selatan sebanyak 43 badan usaha milik negara. 116 sampel.Setyo Hari Wijayanto (2008:146) untuk mengukur reliabilitas dalam SEM varians) dapat menggunakan composite reliability (reliabilitas konsistensi internal) dan variance exctract measure (ukuran ekstrak varian). Selanjutnya model pengukuran reflektif dianggap reliabel, apabila reliabilitas konsistensi internal (composite reliability) dan reliabilitas indikator (loading factor) lebih tinggi dari 0,70. Construct reliability.

$$
\mathrm{CR}=(\Sigma \text { std.loading }) 2
$$

$$
(\Sigma \text { std. loading }) 2+\Sigma \mathbf{e j}
$$

Selanjutnya diketahui ukuran ekstrak varian (varian extracted) harus lebih tinggi dari 0.5, yang dihitung dengan menggunakan rumus sebagai berikut :

\section{Variance Extracted $=\quad \Sigma$ std. loading 2 $\Sigma$ std. loading $2+\Sigma \overline{\mathrm{ej}}$}

Unit pengamatan dalam penelitian ini adalah unit-unit terkait dalam sistem informasi sebagai penyelenggara sistem informasi akuntansi pada badan usaha milik negara. Penelitian ini menggunakan data primer, sedangkan metode pengumpulan data yang digunakan adalah kuesioner.Uji validitas dilakukan yang digunakan untuk menentukan kelayakan item dalam daftar pertanyaan untuk menentukan variabel dan uji reliabilitas untuk mengukur keandalan objek yang diukur.Analisis data dilakukan dengan analisis deskriptif dan verifikasi.

Analisis deskriptif dilakukan dengan kategorisasi yang seimbang dengan menggunakan rentang kuartil (Cooper \& Schindler, 2006; 467). Analisis verifikasi yang digunakan untuk menguji hipotesis dalam penelitian ini adalah dengan menggunakan komponen struktural persamaan pemodelan (SEM, Lisrel ) atau berbasis varians yang dikenal SEM Lisrel. 
Hertanti, Susanto, Zarkasyi, Suharman \& Umar

Tabel 1 Hasil Evaluasi Pengukuran Relevansi Dimensi Formatif

\begin{tabular}{|l|l|l|l|l|l|l|l|}
\hline Latent & Dimensi & Bobot & $\begin{array}{l}\text { Galat } \\
\text { baku }\end{array}$ & Nilai- z & $\begin{array}{l}\text { Nilai- } \\
\mathbf{p}\end{array}$ & Sig & Relevan \\
\hline \multirow{4}{*}{ Etika Organisasi } & Tanggung Jawab & 0,19 & 0,011 & 17,12 & 0,000 & Sig & Relevan \\
\cline { 2 - 8 } & Akuntanbilitas & 0,44 & 0,006 & 58,65 & 0,000 & Sig & Relevan \\
\cline { 2 - 8 } & Keajiban & 0,76 & 0,007 & 101,30 & 0,000 & Sig & Relevan \\
\hline \multirow{2}{*}{$\begin{array}{l}\text { Kualitas Sistem } \\
\text { Anformasi }\end{array}$} & Integration & 0,64 & 0,013 & 33,94 & 0,000 & Sig & Relevan \\
\cline { 2 - 8 } & Flexibility & 0,46 & 0,014 & 43,86 & 0,000 & Sig & Relevan \\
\cline { 2 - 8 } & Reability & 0,45 & 0,013 & 34,25 & 0,000 & Sig & Relevan \\
\hline \multirow{2}{*}{$\begin{array}{l}\text { Kualitas } \\
\text { Akuntansi }\end{array}$} & Accuracy & 0,50 & 0,017 & 32,67 & 0,000 & Sig & Relevan \\
\cline { 2 - 8 } & Relevancy & 0,45 & 0,017 & 26,32 & 0,000 & Sig & Relevan \\
\cline { 2 - 8 } & Timeline & 0,46 & 0,011 & 59,99 & 0,000 & Sig & Relevan \\
\cline { 2 - 8 } & Completeness & 0,46 & 0,013 & 35,21 & 0,000 & Sig & Relevan
\end{tabular}

Sumber: hasil perhitungan komponen skor dengan program $\mathrm{R}$

Berdasarkan informasi yang diperoleh dari tabel 1 memperlihatkan nilai Plebih kecil dari 0,5 maka semua dimensi relevan sebagai alat ukur variabelnya masing-masing.

\section{Tabel 3 Parameter Model Struktural}

\begin{tabular}{ccccccccc}
\hline Akibat & Mediator & Penyebab & $\begin{array}{l}\text { Taksiran } \\
\text { baku }\end{array}$ & Taksiran & $\begin{array}{c}\text { Galat } \\
\text { baku }\end{array}$ & Nilai-z & Nilai-p & Keterangan \\
\hline KSIA & - & EO & 0,52 & 0,360 & 0,20 & 1,81 & 0,865 & Sig \\
& - & IA & 0,66 & 0,061 & 0,07 & 0,86 & 0,796 & Sig
\end{tabular}

Berdasarkan informasi yang diperoleh dari tabel 3, interpretasi hasil evaluasi model persamaan struktural Taksiran bakusetelah seluruh model diuji dan diperoleh model yang fit dengan data maka tahap berikutnya adalah dilakukan pengujian hipotesis.

\section{Hasil Penelitian}

Pengujian Validitas dan Reliabilitas: Semua item pengukuran baik variabel etika organisasi dan kualitas variabel Sistem Informasi Akuntansi dinyatakan valid karena memiliki nilai rhitung $>0,30$, sehingga dapat disimpulkan bahwa alat ukur dalam bentuk pernyataan kuesioner telah memiliki tingkat validitas yang baik (lampiran). Berdasarkan data penelitian, hasil uji reliabilitas baik untuk variabel kuaitas Sistem Informasi Akuntansi (Y) dan untuk variabel etika Organisasi (X) dan Kualitas informasi akuntansi (Z), hal ini menunjukkan bahwa nilai rhitung lebih besar dari 0,7, dapat disimpulkan bahwa pernyataan kuesioner sebagai alat ukur variabel yang digunakan dalam penelitian ini adalah reliabel (rekapitulasi dalam lampiran). 
Hertanti, Susanto, Zarkasyi, Suharman \& Umar

Diketahui penyebab sistem informasi akuntansi yang tidak berkualitas karena beberapa faktor seperti sistem informasi akuntansi yang tersedia pada badan usaha milik negara di Sumatera Selatanbelum fleksibel, tidak mudah digunakan, sulit diakses, tidak aman, belum terintegrasi dengan baik dan sering memiliki kesalahan/gangguan.Badan usaha milik negara di Sumatera Selatanyang belum memiliki prosedur operasi standar/SOP dan untuk badan usaha milik negara di Sumatera Selatanyang sudah memiliki SOP ada karyawan yang tidak melaksanakan pekerjaan sesuai dengan SOP-nya.Serta sistem informasi akunatansi pada badan usaha milik negara di Sumatera Selatan menempatkan orang-orang yang tidak sesuai dengan keahlian bidang pada informasi akuntansi yang tidak akurat, tidak tepat waktu serta ikhtisar.Etika organisasi yang baikakan meningkatkan kualitas sistem informasi akuntansi serta menghasilkan informasi akuntansi yang berkualitas.

\section{Kesimpulan}

Etika organisasi mempengaruhi kualitas sistem informasi akuntansi. Sistem informasi akuntansi pada badan usaha milik negara di Sumatera Selatan tidak memenuhi syarat karena sistem informasi akuntansi yang tidak fleksibel, sulit diakses, belum aman, tidak terintegrasi dengan baik dan sering memiliki kesalahan/gangguan karena belum terkomfirmasi oleh informasi akuntansi yaitu belum akurat, blum tepat waktu dikuatirkan salah dalam pengambilan keputusan serta berakibat pada informasi akuntansi yang tidak berkualitas. Etika organisasipada badan usaha milik negara di Sumatera Selatan tidak optimal karena masih ada pembagian tugas (pembagian kerja), pengelompokan tugas dan tanggung jawab dan pemberian tugas instruksi (wewenang komando) terdapat banyak rangkap jabatan yang berimplikasi penyalagunaan wewenang karena dipegang oleh satu orang, serta formalisasi pekerjaan yang belum bagus.

\section{Ucapan Terima Kasih}

Penelitian ini didukung oleh Direktorat Jenderal Pendidikan Tinggi, Kementerian Riset, Teknologi, dan Pendidikan Tinggi Republik Indonesia Indonesia. Terima kasih unit-unit fungsional terkait pada BUMN di SUMSEL Indonesia untuk mengisi kuesioner dan tanggapan guna memberikan wawasan 
Hertanti, Susanto, Zarkasyi, Suharman \& Umar

dan keahlian yang sangat membantu penelitian, meskipun mereka mungkin tidak setuju dengan semua interpretasi / kesimpulan dari makalah ini.

\section{DAFTAR PUSTAKA}

Alzoubi, Ali. 2011. The Effectiveness of The Accounting Information System Under the Enterprise Resources Planning (ERP). Research Journal of Finance and Accounting. Vol 2.No. 11. Pp. 10-18.

Azhar Aziz. H 2014. Penyimpangan Anggaran Naik. Melalui http://www.bpk.go.id/news /penyimpangan-anggaran-naik.3 Desember 2014.

Ballantine, J, Levy M, Martin A, Munro I \& Powell P. 2000. An Ethical Perspective on Information Systems Evaluation.International Journal of Agile Management Systems 2/3. Pp 233-241.

Baltzan, Paige. 2014. Business Driven Information Systems. 4th Edition.USA : McGraw-Hill

Barganof, Nancy A; Mark G.Simkin dan Carolyn S. Norman. (2010), "Core Concept of Accounting Information Systems", Eleventh edition. Jhon Willey \& Sons, USA.

Budi. J.2011. Direktur Keuangan PT Barata Indonesia Jadi Tersangka KPK. Melalui http://sp. beritasatu.com/home/direktur-keuangan-pt-barata-indonesiajadi-tersangka-kpk/4409. 10 Maret 2011

Bodnar, George. H dan William S. Hoopwood.(2014), “Accounting Information Systems. Pearson Education Limited, USA.

Boockholdt, J.L. (1999), "Acounting Information Systems", Fifth Edition. Singapore: Mc. GrawHill.

Bocij, Paul, Grasley, Andrew \& Simon Hickie. 2008. Business Information System : Technology, Development \& Management. Fourth Edition.USA : Prentice Hall.

Chen, Charlie C, Liu, Julie Yu Chih, Chen, Houn Gee. 2011. Discriminative Effect of User Influence and User Responsibility on Information System Development Processes and Project Management. Information and Software Technology. Pp. 149-158.

Cooper, D. R \& Schindler, Pamela S. (2014), "Business Research Method", Twelfth Edition. Singapore: Mc. GrawHill.

Dessler, Gary. 2013. Human Resources Management. Twelfth Edition.USA : Prentice Hall

Gelinas, Ulrich J \& Richard B. Dull. (2008), "Accounting Information System".Seventh Edition. Canada: Thomson South-Western a part of The Thomson Corporation

Griffin, Ricky W. \& Moorhead, Gregory. 2014. Organizational Behavior Managing People and Organizations. 11th Edition.Canada : South Western Cengage Learning.

Guragai, Binod, Hunt Nicholas \& Neri, March. 2014. Accounting Information Systems and Ethics Research : Review, Synthesis and the Future. Social Science Research Network. Pp. 1-40.

Gorla, Narasimhaiah, Somers, Toni M \& Wong, Betty. 2010. Organizational Impact of System Quality, Information Quality, and Service Quality. Journal of Strategic Information Systems. 2010. Pp 207-228. 
Hertanti, Susanto, Zarkasyi, Suharman \& Umar

Rogerson, Simon, Weckert, John \& Simpson, Chris. 2000. An Ethical Perspective on Information Systems Evaluation. International Journal of Agile Management Systems 2/3. 2000. Pp 233-241

Hall, James A. (2011), “Accounting Information System”, Seventh edition.South Western Cengage Learning, USA.

Hansen, Don R. \& Mowen, Maryanne M. 2007. Managerial Accounting.8th Edition. USA: Thomson South Western

Hair.Jr.J.F.Hult.G.T.M., Ringle, C.M \& Sarted.,M 2014 A Primer on Partial Least Squares Structural Equation Modeling (PLS-SEM). Califrnia : sage Publication, Inc

Hansen, D.R. \& Mowen, M.M.2007. Managerial Accounting, Eighth Edition. Mason: Thomson Sounth-Western.

Hertati.L 2015. Competence of Human Resources, The Benefits of Information Technology on Value of Financial Reporting in Indonesia. Research Journal of Finance and Accounting www.iiste.org.ISSN 2222-1697 (Paper) ISSN 22222847 (Online) Vol.6, No.8, 2015

Hertati.L.2015. Impact of uncertainty of environment and organizational cultural on accounting information system management and implications for managerial performance proposing a conceptual framework. International Journal of Economics, Commerce and Management United Kingdom Vol. III, Issue 12, December 2015 Licensed under Creative Common Page 455 http://ijecm.co.uk/ ISSN 23480386

Hertati.L. 2015.Total Quality Management As Technics On Strategic Management Accounting. International Journal of Recent Advances in Multidisciplinary ResearchVol. 02, Issue 11, pp.0942-0949, November, 2015

Hertati, L.2015. Internal Control And Ethics Of Quality Management System Accounting Information And Implications On The Quality Of Accounting Information Management: Proposing A Research Framework. International Journal of Economics, Commerce and Management United Kingdom Vol. III, Issue 6, June 2015 Licensed under Creative Common Page 902 http://ijecm.co.uk/ ISSN 23480386

Hertati.L. 2016. Just In Time, Value Chain, Total Quality Management, Part Of Technical Strategic Management Accounting. International Journal Of Scientific \& Technology Research Volume 5, Issue 04, April 2016 Issn 22778616

Hertati, and Sumantri 2016. Just In Time, Value Chain, Total Quality Management, Part Of Technical Strategic Management Accounting.International Journal Of Scientific \& Technology Research Volume 5, Issue 04, April 2016 Issn 2277-8616.

Hertati.L. 2019.The Effect of Human Resource Ethics on Financial Reporting Implications for Good Government Governance (Survey of Related Sub-units in State-owned Enterprises in SUMSEL). International Journal of Economics and Financial Issues ISSN: 2146-4138 available at http: www.econjournals.com International Journal of Economics and Financial Issues, 2019, 9(4), 267-276

Horan, Thomas A \& Abhichandani, Tarun. 2006. Evaluating User Satisfaction in an E-Government Initiative : Resulte of Structural Equation Modeling and 
Hertanti, Susanto, Zarkasyi, Suharman \& Umar

Focus Group Discussions. Journal of Information Technology Management. Pp. 187-198.

Husein Umar. (2003), Metodologi Penelitian Untuk Skripsi dan Tesis Bisnis, PT. Gramedia Pustaka, Jakarta :

Ivancevich, Jhon. M; Robert Konopaske; and Michael T. Matteson. 2011. Organization Behaviour and Management. Ninth Edition.

Ives, B; Olson, M.H; and Baraoudi, J. (1983), "The Measurement Of User Information satisfaction", Communications of The ACM. 26 October. Pp.785793.

Ives, B \& Olson, M.H. (1984), "User Involvement and MIS Success, A Review of Research", Management Science. 30 (5).Pp. 205-223.

Indeje, Wanyama G \& Qin Zheng. (2010), "Organizational Culture and Information Systems Implementation: A Structuration Theory perspective", Sprouts: Working Papers on Information Systems. 10 (27).

Koskosas, Ioannis, Kakoulidis, Konstantinos \& Siomos, Christos. 2011. Information Security : Corporate Culture and Organization Commitment. International Journal of Humanities and Social Science. Vol 1.No. 3. Pp. 192198.

Laudon, Kenneth C and Jane P Laudon. (2014), "Management Information System: Managing The Digital Firm", Thirteenth Edition South-Western Cengage Learning, USA.

Masclet, Laurence \& Goujon, Philippe. 2012. Implementing Ethics in Information Systems, Presuppositions and Consequences in Ethics and Information Systems. International Federation for Information Processing.Pp. 287-298

Marakas, George M \& James A. O'Brien.(2014), "Introduction to information System", Sixtheenth Edition.McGraw-Hill.Inc. Boston.

Mc. Leod, Raymond \& Schell, George P. 2007. Management Information System.Tenth Edition. Upper Saddle River New Jersey 07458 : Pearson / Prentice Hall.

Mc. Shine, Stephen L and Mary Ann Von Glinow.(2010), "Organizational Beahaviour: Emerging Knowledge And Practiace for the Real Word", Mc. Graw Hill, USA.

Mulyani. S. 2009. Sistem Informasi Manajemen Rumah Sakit : Analisis dan Perancangan. Bandung: Abdi Sistematika.

Mulyani. 2014. Sistem Informasi Akuntansi. Tangerang Selatan : Universitas Terbuka.

Munteanu, Victor, Zuca, Marilena \& Tinta, Alice. 2007. The Financial Accounting Information System Central Base in The Managerial Activity of an Organization. Cod JEL M41 - Accounting.

Uchok Sky Khadafi, 2012.PT Telkom Berpotensi Jadi BUMN Terkorup.Melalui http://www.tempo.co/read/news/2012/07/16/090417171/PT-TelkomBerpotensi-Jadi-BUMN-Terkorup.16 Juli 2012.

O’Brien, James A. \& Marakas, George M. 2011. Management Information Systems. Tenth Edition. New York: McGraw-Hill Irwin.

Nicolau, A.I. (2000), "A Contigency Model Perceived Effectiveness in Accounting Information Systems: Organizational condition and controll Effect", International Jurnal Of Accounting Information System. 1(2). 
Hertanti, Susanto, Zarkasyi, Suharman \& Umar

Olson, David L. (2003), "Introduction To Information System Project Management", Second edition, Mc.Graw-Hill, USA.

Olumoye, Mosud Y. 2013. Ethics and Social Impact of Information Systems in Our Society : Analysis and Recommendation. International Journal of Science and Research.Pp. 154-158.

O'Brien, James A. \& Marakas, George M. 2011. Management Information Systems. Tenth Edition. New York: McGraw-Hill Irwin.

Onaolapo A.A and Odetayo T.A. 2012. Effect of Accounting Information System on Organisational Effectiveness : A Case Study of Selected Construction Companies in Ibadan Nigeria. American Journal of Business and Management.Vol. 1.No. 4. 2012. 183-189.

Piccoli, Gabriele. 2008. Information Systems for Managers. Text and Cases. USA: John Wiley \& Sons Inc. United States of America.

Post, G. V \& Anderson, D. L. (2003), "Management Information Systems Solving Business Problems with Information Technology", Third Edition. McGrawHill, Singapore.

Ralph, M. Stair \& George Reynold. (2012), "Fundamental Of Information Systems", Sixth Edition, Cengage Learning, USA.

Robbins, P. Stephen \& Judge, A. Timothy. (2014), "Organizational Behavior", Jakarta: Salemba 4

Rogerson, Simon, Weckert, John \& Simpson, Chris. 2000. An Ethical Perspective on Information Systems Evaluation. International Journal of Agile Management Systems 2/3. 2000. Pp 233-241

Rocheleau, Bruce. 2006. Public Management Information System. 2006. All rights Reserved.

Romney, Marshall B and Steinbart, Paul John.(2012), “Accounting Information Systems", Tenth Edition. Pearson Education, USA.

Sacer, Ivana Mamic; Katarina Zager, Boris Tusek. (2006), "Accounting Information System's Quality as The Ground for Quality Business Reporting", IADIS International Conference e-Commerce.

Sajady, Dastgir, Hashem Nejad. 2008. Evaluation of The Efectiveness of Accounting Information Systems. International Journal of Information Science and Technology.Vol. 6.No. 2. July/December

Schwalbe, Kathy. 2006. Introduction to Project Management. Course Technology Thomson Learning. Inc. USA : Cengage Learning, Inc. Boston, Massachussetts

Simkin, Mark G, Rose, Jacob M \& Norman, Carolyn Strand. 2013. Accounting Information Systems. Twelfth Edition.Singapore : John Wiley.

Susanto.A.(2008), "Sistem Informasi Akuntansi (Struktur-Pengendalian-ResikoPengembangan", Lingga Jaya, Bandung.

Susanto.(2009), "Sistem Informasi Manajemen: Pendekatan Terstruktur Risiko Pengembangan", Lingga Jaya, Bandung

Susanto.A.( (2013), "Sistem Informasi Akuntansi: Struktur-Pengendalian-ResikoPengembangan", Lingga Jaya, Bandung.

Susanto.A.( (2013), "Sistem Informasi Manajemen: Pendekatan Terstruktur Risiko-Pengembangan", Lingga Jaya, Bandung.

Susanto.A.( (2013), “Teknologi Informasi untuk Bisnis \& Akuntansi”, Lingga Jaya, Bandung. 
Hertanti, Susanto, Zarkasyi, Suharman \& Umar

Susanto. (2015), "Influence The Quality of Accounting Information on The Implementation Good Study Program Governance", International Journal Of Science \& Technology Research (IJSTR). Volume 4 - Issue 12, December 2015 Edition - ISSN 2277-8616. Page 326

Susanto.A.(2016.The influence of Accounting Information System Quality to Accounting Information Quality and its Implication to the Good Study of Governance Programs International Business Management 10 (24): 57675776,2016 ISSN: 1993-5250 Medwel Journl, 2016

Susanto.A.( 2016.The Effect of Internal control and Accounting Information System. 10 (243): 5523-5529,2016 ISSN: 1993-5250 medwel Journl, 2016 Medwel Journl, 2016

Sumarjati Arjoso. 2013. BAKN DPR: Banyak penyimpangan anggaran di BUMN. Melalui http://nasional.kontan.co.id/news/bakn-dpr-banyak-penyimpangananggaran-di-bumn.20 Nopember 2013.

Scott, George M. 1986. Principles of Management Information System. New York: McGraw-Hill, Inc.

Scott, George M. (2001), "Principle Of Management Information System", Mc.GrawHill, USA.

Seddon, P \& Yip, S.K. (1992), “An Emprirical Evaluation of user Information Satisfaction (UIS) measures for use with General Ledger Accounting Software", The Journal Of Information Systems, Vol. VI No.1 (Spring).

Stair, Ralph M \& George Reynold.(2012), "Fundamental of Information Systems", Sixth edition, Cengage Learning, USA.

Sigit Haryanto. (2015). Menteri Agama Inginkan Sistem Informasi Seluruh Satker Terintegrasi.http://bimasislam.kemenag.go.id/post/berita. 14 Januari 2015.

Simkin, Mark G, Rose, Jacob M \& Norman, Carolyn Strand. 2013. Accounting Information Systems. Twelfth Edition.Singapore : John Wiley.

Taufiqurohman Ruki. (2011), BPK: Sistem Informasi Akuntansi Pajak Masih Lemah. http://www.kompas.com.

Weber, Ron. 1999. Information System Control and Audit. USA : Prentice-Hall International

Wilkinson, Joseph W; Cerullo, Michael J; Raval, Vasant \& Wong-on-wing, Bernard. (2000), "Accounting Information Systems: Essential Concepts and Applications, $4^{\text {th }}$ edition", John Wiley and Sons, USA.

William H. Delone, Ephraim R. McLean. (2003), "Information Systems Success: TheQuest for the Dependent Variable", Information System Research The Instituteof Mangement Science. Pg 15

Wongsim, M., \& Jing Gao. 2011. Exploring Information Quality in Accounting Information System Adoption. IBIMA Publishing. Pp. 1-12.

$\mathrm{Xu}$, Hongjiang. 2009. Data Quality Issues for Accounting Information System' Implementation : Systems, Stakeholders and Organizational Factors. Journal of Technology Research

Yarmohammad, Zahed. (2011), “The Analysis Of The Relationships between Organizational Structure and Information Technology (IT) and the barriers to its establishment at the University of Isfahan From the Faculty Member's Viewpoints", Higher Education Studies, Vol 1. No.1, June: Publish by Canadian Center Of Science and Education 